\title{
ANALISA BENTUKAN FASAD RUMAH KHAS BETAWI PADA PERKAMPUNGAN BUDAYA BETAWI SETU BABAKAN
}

\author{
Form Analysis of Betawi Traditional House Facade \\ in Betawi Cultural Village Setu Babakan
}

\author{
Dian Monica Erveline Basri ${ }^{1}$, Erick Denhas ${ }^{2}$, \\ 1234 Jurusan Arsitektur, Tanri Abeng University \\ Email: monica.basri@tau.ac.id
}

\begin{abstract}
Abstrak
Seiring bertambahnya penduduk yang tinggal di kota Jakarta, arsitektur rumah tradisional Betawi juga terpengaruh. Banyak rumah Betawi yang elemen Betawinya sudah bercampur dengan arsitektur modern. Penelitian ini dilakukan dengan menganalisa fasad rumah Betawi, untuk mengetahui apakah arsitektur rumah Betawi yang dijadikan sample penelitian sudah terpengaruh elemen arsitektur modern atau belum. Dan seberapa banyak pengaruhnya. Setu Babakan dipilih menjadi studi kasus, sebab merupakan kawasan cagar budaya rumah Betawi. Penelitian dilakukan dengan cara mengobservasi studi kasus, kemudian mengelompokkan elemen-elemen fasad, lalu membandingkan elemen-elemen fasad tersebut dengan arsitektur rumah Betawi, untuk kemudian diketahui apakah terdapat elemen arsitektur modern didalamnya dan seberapa banyak elemen arsitektur modern yang terdapat pada fasad rumah Betawi tersebut. Setelah dilakukan penelitian, diketahui bahwa banyak arsitektur rumah Betawi yang telah dipengaruhi elemen arsitektur modern pada fasadnya.
\end{abstract}

Kata kunci: Setu Babakan, Fasad, Rumah Adat Betawi

\section{PENDAHULUAN}

Dikutip dari portal berita bbc.com, Pemerintah DKI Jakarta memperkirakan jumlah pendatang baru di Jakarta setelah masa Idul Fitri 2019 akan mencapai 71.000 atau meningkat sebanyak 2.000 orang dibandingkan tahun lalu. Dari sini dapat diketahui bahwa semakin hari, penduduk kota Jakarta semakin bertambah. Masyarakat yang berasal dari luar daerah tersebut, memiliki andil dalam mengubah wajah arsitektur rumah Betawi. Fasad arsitektur rumah Betawi saat ini sudah mengalami perubahan dibandingkan aslinya. Untuk mengetahui seberapa banyak elemen arsitektur modern yang mempengaruhi fasad arsitektur rumah Betawi, maka dilakukanlah penelitian ini. Dari hasil penelitian ini, diharapkan ke depannya, pihak pembangun memahami elemen arsitektur fasad yang hendak digunakan dalam merencanakan arsitektur rumah Betawi, sehingga fasad asli arsitektur rumah Betawi dapat dilestarikan.

\section{METODE}

Penelitian ini dilakukan dengan dengan mengunjungi studi kasus di area perkampungan Setu Babakan Betawi untuk mengamati dan mendokumentasikan bangunan-bangunan rumah adat Betawi. Dari hasil observasi tersebut, bangunan dikelompokkan berdasarkan elemen-elemen fasadenya. Setelah itu, hasil pengelompokan jenis rumah digambarkan secara deskriptif berdasarkan data rujukan dari sumber teori dari buku "RUMAH TRADISIONAL BETAWI" karya Ismet Belgawan Harun dan "RUMAH 
ETNIK BETAWI" karya Doni Swadarma dan Yunus Aryanto.

\section{LOKASI PENELITIAN}

Setu Babakan berlokasi di Srengseng Sawah, kecamatan Jagakarsa, Jakarta Selatan. Setu Babakan merupakan cagar budaya khusus budaya Betawi yang terletak di pinggir danau buatan. Menurut data dari Unit Pengelola Kawasan (UPK) PBB Setu Babakan, luas perkampungan Setu Babakan yaitu 289 Hektar, dimana 65 hektar di antaranya adalah milik pemerintah, namun yang baru dikelola yaitu hanya 32 hektar. Kondisi beberapa rumah di kawasan tersebut masih terlihat seperti rumah adat Betawi pada umumnya, namun sebagian rumah penduduk telah bercampur dengan gaya arsitektur modern. Untuk mengetahui dan membedakan kedua unsur ini, khususnya pada bagian fasad rumah.

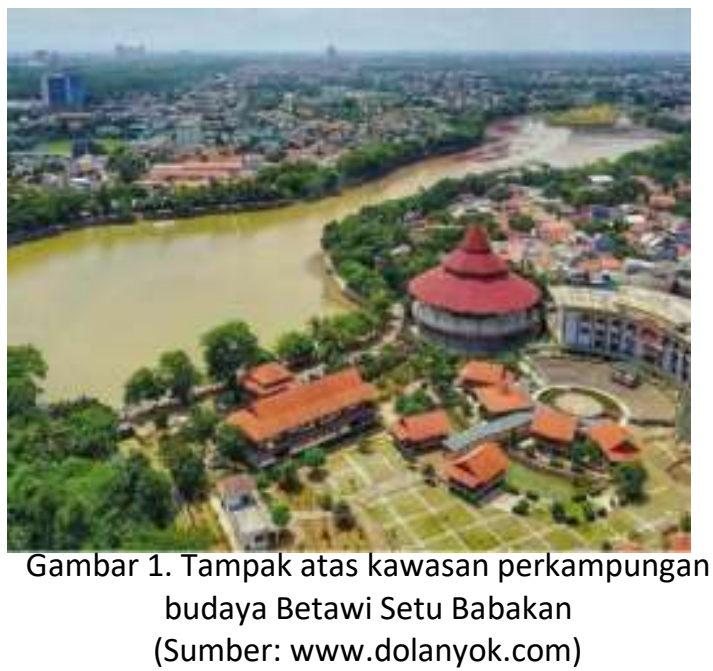

\section{PEMBAHASAN}

\section{LANDASAN TEORI}

Dikutip dari buku Rumah Etnik Betawi (Doni Swadarma, Yunus Aryanto, 2013), pada dasarnya rumah adat Betawi memiliki 4 jenis yang berbeda yakni rumah kebaya / bapang, rumah gudang, rumah joglo Betawi, dan rumah panggung Betawi. Masing-masing rumah ini memiliki ciri khasnya sendiri, terutama dalam fasadnya.

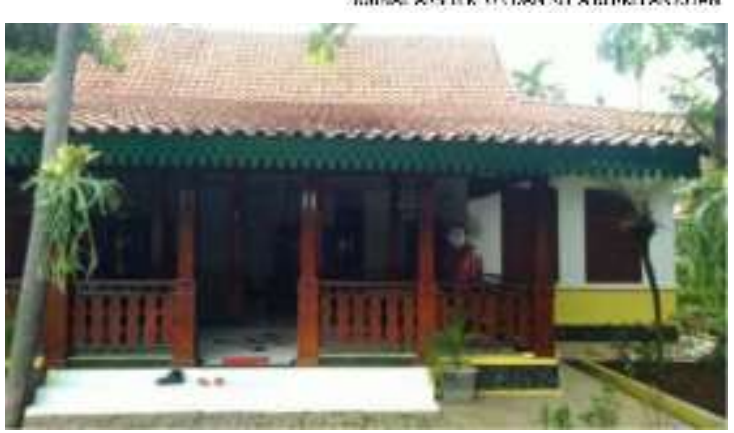

Gambar 2. View fasade rumah kebaya (Sumber: Dokumentasi pribadi)

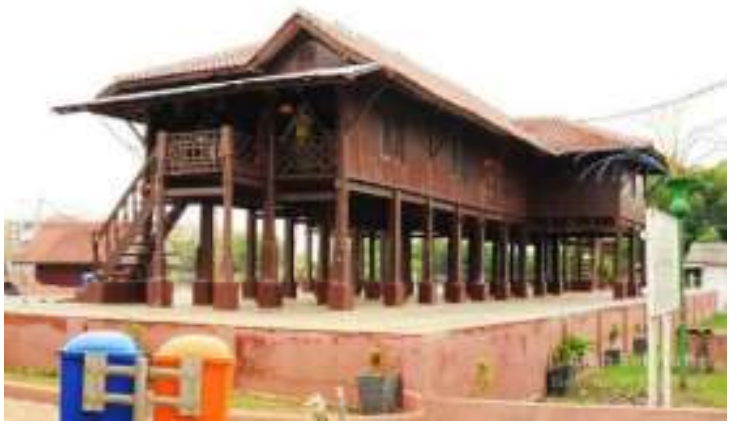

Gambar 3. View rumah panggung Betawi (Sumber: www.urbanexplorers.asia)

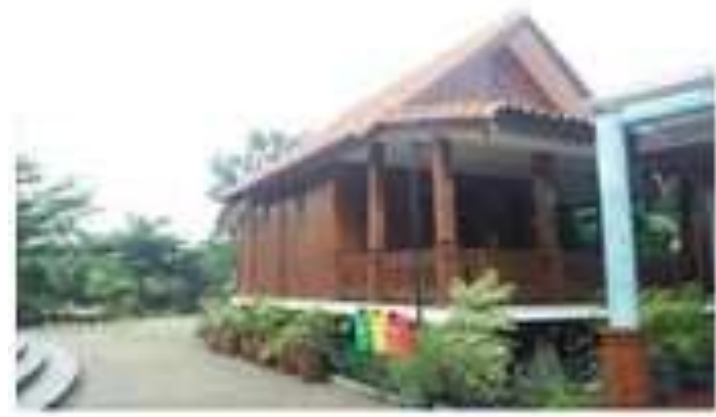

Gambar 4. View rumah gudang

(Sumber: Dokumentasi pribadi)

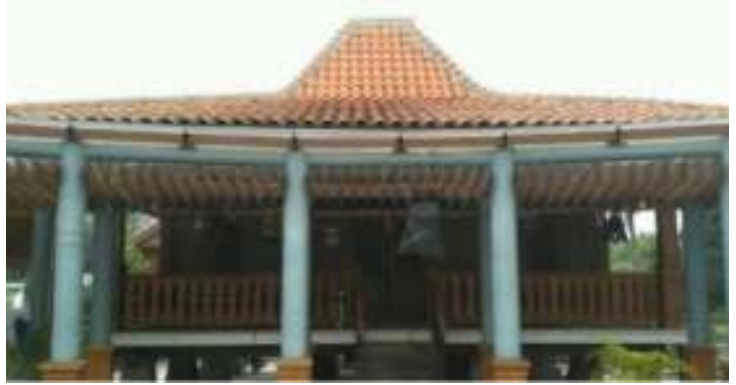

Gambar 5. View fasade rumah joglo Betawi

(Sumber: Dokumentasi pribadi)

Fasad semua rumah adat Betawi dibuat terbuka, dengan filosofi bahwa masyarakat Betawi umumnya sangat terbuka dan siap menerima pengaruh dari luar. Unsur-unsur pembentuk fasad rumah Betawi pada umumnya terdiri dari: atap, dinding, jendela, pintu, langkan (pagar pembatas teras), dan beberapa ornamen lainnya (ornamen ukiran pada kolom, ornamen diatas pintu dan jendela, 
ornamen gigi balang pada lisplank, ornamen pada sopi-sopi atap, dan lain sebagainya). Walaupun semua unsur ini merupakan ornamen Betawi, namun kebanyakan unsur tersebut adalah hasil akulturasi dengan budaya lain, sehingga kerap kali ditemui beberapa kemiripan antara beberapa bagian rumah Betawi dengan bagian dari rumah-rumah adat daerah lain. Selain itu, zaman yang semakin modern, juga turut membuat rumah Betawi sedikit demi sedikit diterpa trend modernisasi, khususnya dalam arsitektur rumah adatnya. Beberapa sudah mulai membangun rumah khas Betawi yang dicampur oleh macammacam gaya arsitektur modern, atau memakai bahan-bahan modern untuk membangunnya.

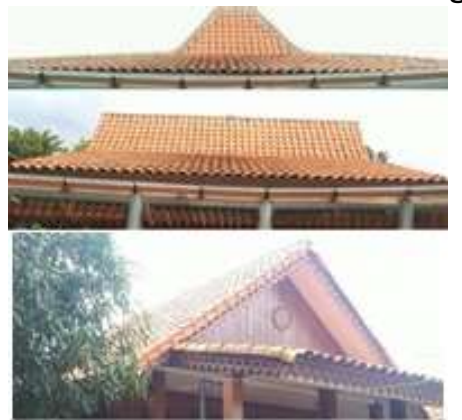

Gambar 6. Atap joglo (atas), bapang (tengah), gudang (bawah), model-model atap yang biasa dipakai pada rumah-rumah adat Betawi

(Sumber: Dokumentasi pribadi)

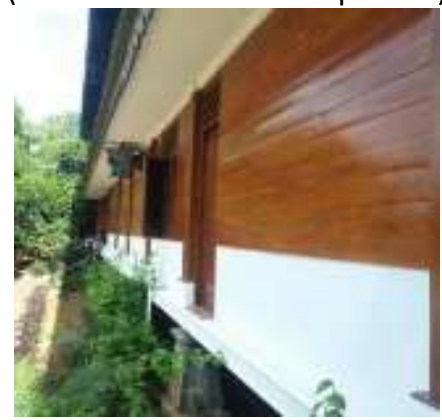

Gambar 7a. Material dinding yang biasa dipakai pada rumah-rumah adat Betawi. Terkadang ada rumah yang dindingnya memakai kayu saja, ada juga yang dinding bata saja, dan ada pula yang memakai keduanya sekaligus

(Sumber: Dokumentasi pribadi)

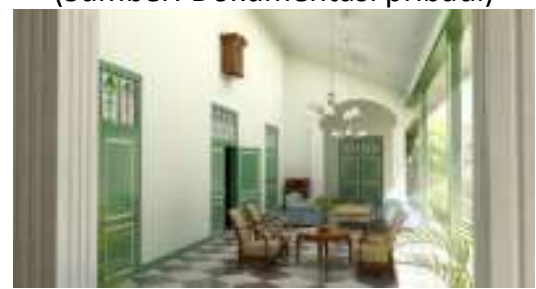

Gambar 7b. Contoh rumah Betawi yang memakai dinding bata

(Source: Rumah Etnik Betawi) ARSITEKTA

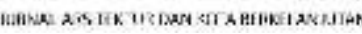

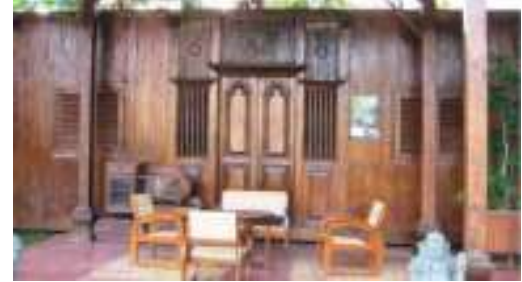

Gambar 8a. Model pintu dan jendela yang menyatu dalam gebyok khas Betawi

(Sumber: tokobarangantik.blogspot.com)

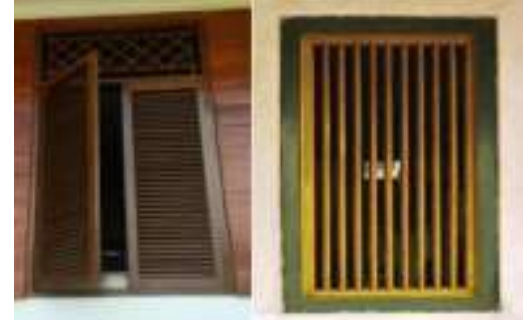

Gambar 8b. Model pintu satu daun (kiri) dan pintu utama dua daun modern (kanan) pada rumahrumah adat Betawi di Setu Babakan. Biasanya memakai material kayu mulai dari kusen, daun, hingga ukiran ornamennya. Pada model yang lebih tradisional biasanya daun pintu memakai model krepyak.

(Sumber: Dokumentasi pribadi)

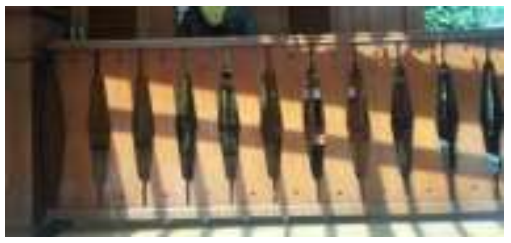

Gambar 10. Langkan / pagar pembatas pada teras rumah adat Betawi, yang memiliki filosofi sebagai penghalang pengaruh-pengaruh buruk dari luar rumah agar tidak masuk kedalam rumah (Sumber: Dokumentasi pribadi)

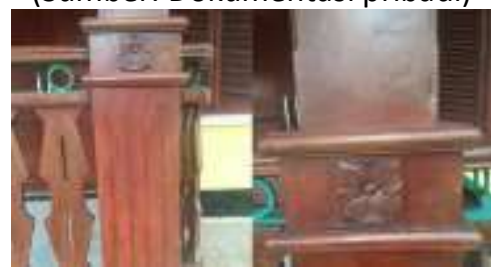

Gambar 11a. Ukiran bunga tapak dara pada kolom kayu, ukiran yang biasanya terdapat pada tiang rumah Betawi

(Sumber: Dokumentasi pribadi)

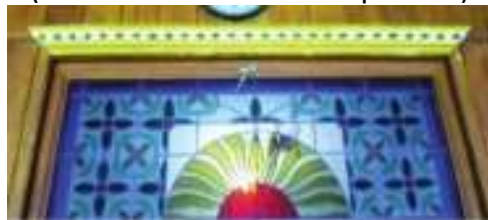

Gambar 11b. Ornamen banji / swastika, ornamen hasil akulturasi dengan budaya Cina ini menyerupai pola penggambaran peredaran bintang / matahari. Sering dijumpai pada bagian 
atas pintu rumah-rumah adat Betawi, dan biasanya terbuat dari kaca patri / ukiran kayu (Sumber: Rumah Etnik Betawi)

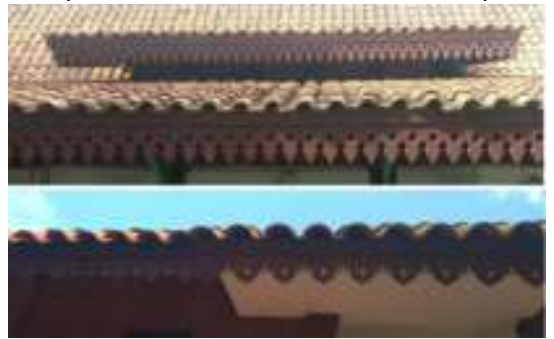

Gambar 12a. Lisplang gigi balang, hasil akulturasi dengan budaya Melayu (atas, akulturasi bentuk ornamen) dan Belanda (bawah, akulturasi bentuk

ornamen dan penerapan lisplang, dimana pemakaian lisplang pada atap rumah dikenalkan pertama kali oleh orang Belanda) yang terdapat pada ujung overhang dan outridger atap rumahrumah adat Betawi

(Sumber: Dokumentasi pribadi)

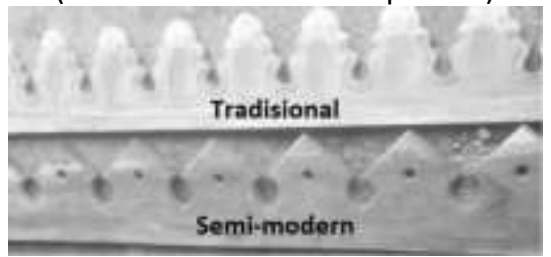

Gambar 12b. Perbandingan lisplang gigi balang

(Sumber: Rumah Tradisional Betawi)

Untuk lebih jelasnya berikut tabel perbandingan deskriptif atas perubahan material pada transisi rumah Betawi menuju modern, pada bagian fasad rumah:

\begin{tabular}{|c|c|c|c|}
\hline \multicolumn{4}{|c|}{$\begin{array}{c}\text { Tabel 1: Perubaban material pada transisi rumah } \\
\text { Betawi menuju modern } \\
\text { (source: buku RUMAH ETNIK BETAWI) }\end{array}$} \\
\hline \multirow{2}{*}{$\begin{array}{l}\text { Bagian } \\
\text { rumah }\end{array}$} & \multicolumn{3}{|c|}{ Perkembangan } \\
\hline & Tradisional & Semimodern & Modern \\
\hline Dinding & $\begin{array}{l}\text { Pada awalova } \\
\text { berdinding. } \\
\text { kaxy / bilik } \\
\text { bamby }\end{array}$ & $\begin{array}{l}\text { Mulai } \\
\text { congenal } \\
\text { dinding bata, } \\
\text { meski hanxa } \\
\text { dinding } \\
\text { setengab } \\
\text { (bagian bawab } \\
\text { bata bagian } \\
\text { atas papan) }\end{array}$ & $\begin{array}{l}\text { Hampir } \\
\text { semua. } \\
\text { dinding } \\
\text { terbuat } \\
\text { daribata / } \\
\text { betea. }\end{array}$ \\
\hline $\begin{array}{l}\text { Kolom } \\
\text { dan } \\
\text { Balok }\end{array}$ & $\begin{array}{l}\text { Tidak mengenal } \\
\text { kolom betoa } \\
\text { bertulang, yang } \\
\text { ada banya } \\
\text { balok dan } \\
\text { kolom dari kayy } \\
\text { terutama kayu } \\
\text { nangka kecapi, } \\
\text { sawe, dan } \\
\text { rambutan }\end{array}$ & $\begin{array}{l}\text { Sudaha } \\
\text { mengenal dan } \\
\text { menggunakan } \\
\text { kolom dan } \\
\text { struktur beton } \\
\text { bertulang. }\end{array}$ & $\begin{array}{l}\text { Sudah } \\
\text { menggu- } \\
\text { nakad } \\
\text { kenstruksi } \\
\text { baia. }\end{array}$ \\
\hline
\end{tabular}

ARSITEKTA

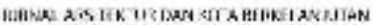

\begin{tabular}{|c|c|c|c|}
\hline $\begin{array}{l}\text { Penutu } \\
\text { p atap }\end{array}$ & $\begin{array}{l}\text { Beratar } \\
\text { sedechana_dari } \\
\text { bahada-baban } \\
\text { yang tersedia, di } \\
\text { alam (ijuk. } \\
\text { rumbia, oll) }\end{array}$ & $\begin{array}{l}\text { Mulai berganti } \\
\text { dengan atap } \\
\text { seng, asbes, } \\
\text { atay_genteag } \\
\text { tanah liat }\end{array}$ & $\begin{array}{l}\text { Penutug } \\
\text { atap dari } \\
\text { genteng } \\
\text { modern } \\
\text { (geateng } \\
\text { geton. } \\
\text { genteng } \\
\text { metal, } \\
\text { spandek. } \\
\text { dll }\end{array}$ \\
\hline $\begin{array}{c}\text { Bentuk } \\
\text { rangka } \\
\text { atap }\end{array}$ & $\begin{array}{l}\text { Dikenal gengan } \\
\text { tiga model: } \\
\text { bagang (bentuk } \\
\text { atap rumah } \\
\text { kebaya), jogle. } \\
\text { dan gudang, } \\
\text { Semua model } \\
\text { atap ini } \\
\text { berbahankavu }\end{array}$ & $\begin{array}{l}\text { Model rangka } \\
\text { atap masih } \\
\text { dioentahankan } \\
\text { materiainya bana } \\
\text { saia yang } \\
\text { mulaj } \\
\text { menuesuaikan }\end{array}$ & $\begin{array}{l}\text { Model } \\
\text { rangka } \\
\text { atap masila } \\
\text { dipertabaa } \\
\text { kad banxa } \\
\text { material- } \\
\text { nxa sudah } \\
\text { mulai } \\
\text { memakai } \\
\text { baia ringan } \\
\text { atay baia } \\
\text { berat }\end{array}$ \\
\hline $\begin{array}{l}\text { Pintu } \\
\text { dan } \\
\text { Jendela }\end{array}$ & $\begin{array}{l}\text { Biasanva. } \\
\text { menggunakan } \\
\text { model gintu \& } \\
\text { jendela. } \\
\text { krepxak, galam } \\
\text { satu kesatuan } \\
\text { dengan gebuok }\end{array}$ & $\begin{array}{l}\text { Masih } \\
\text { digunakan } \\
\text { tetapi sudab } \\
\text { tidak satu } \\
\text { kesatuan } \\
\text { dengan } \\
\text { Gebuok }\end{array}$ & $\begin{array}{l}\text { Sebagian } \\
\text { hanxa } \\
\text { menggu- } \\
\text { nakan } \\
\text { moglelnua } \\
\text { saja } \\
\text { dengan } \\
\text { struktur \& } \\
\text { bahan } \\
\text { yang } \\
\text { berbeda }\end{array}$ \\
\hline Langkan. & $\begin{array}{l}\text { Langkan kaxu } \\
\text { tradisjonal } \\
\text { merupakan } \\
\text { satu kesatuan / } \\
\text { berdampingan } \\
\text { dengan tapang } \\
\text { dan paseban }\end{array}$ & $\begin{array}{l}\text { Langkan } \\
\text { yang } \\
\text { divariasikan } \\
\text { dengan } \\
\text { tembok bata. }\end{array}$ & $\begin{array}{l}\text { Langkan } \\
\text { Jarang } \\
\text { digunakan, } \\
\text { sekalinun } \\
\text { ada haroxa } \\
\text { meniadi } \\
\text { gemanis } \\
\text { teras } \\
\text { berbahan } \\
\text { baja/ besi } \\
\end{array}$ \\
\hline Lisplang & $\begin{array}{lr}\text { Lisplang } & \text { gigi } \\
\text { balang } & \text { meniadi } \\
\text { ikon } & \text { rymah } \\
\text { Betawi } & \text { yang } \\
\text { biasanya } & \\
\text { terbuat } & \text { gari } \\
\text { kavy } & \text { yang } \\
\text { diukir } & \text { gengan } \\
\text { ragam } & \text { hias } \\
\text { tombak } & \\
\end{array}$ & $\begin{array}{lr}\text { Model lisplang } \\
\text { lebih simpel } \\
\text { baik } & \text { gari } \\
\text { bahana } & \\
\text { maupun } & \\
\text { desain } & \end{array}$ & $\begin{array}{l}\text { Sekedac } \\
\text { srnamea } \\
\text { dekoratif } \\
\text { yang tidak } \\
\text { selalu adda }\end{array}$ \\
\hline
\end{tabular}




\section{HASIL OBSERVASI DAN ANALISA}

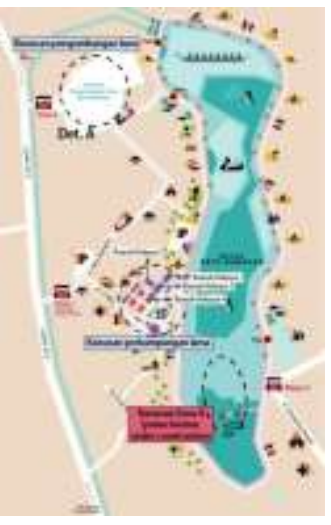

Gambar 13. Siteplan Kawasan Setu Babakan (Sumber:

www.kesetubabakannyok.wordpress.com)

Rumah adat Betawi yang berada di Kawasan perkampungan budaya Betawi Setu Babakan tersebar di beberapa lokasi, yakni kawasan perkampungan lama, kawasan pengembangan baru, dan kawasan Pulau Buatan (ketika penelitian ini dilakukan, kawasan ini sedang di revitalisasi).

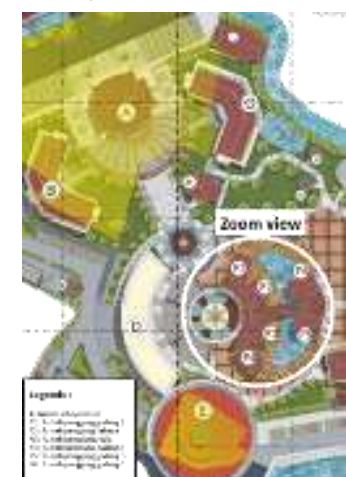

Gambar 14. Detail A: Siteplan rencana kawasan pengembangan baru Setu Babakan

(Sumber: Seminar Material - Perkampungan Budaya Betawi (PBB) di Setu Babakan Kec. Jagakarsa Jakarta Selatan)

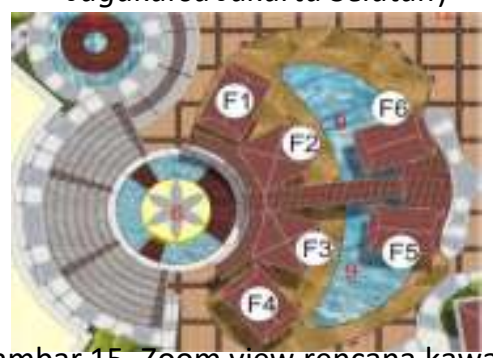

Gambar 15. Zoom view rencana kawasan pengembangan baru Setu Babakan

(Sumber: Seminar Material - Perkampungan Budaya Betawi (PBB) di Setu Babakan Kec. Jagakarsa Jakarta Selatan)
Setelah dilakukan observasi teradap 4 unsur utama fasad (atap, langkan, sirkulasi bukaan, ornamen) pada 10 rumah sebagai studi kasus penelitian pada kawasan perkampungan budaya Betawi Setu Babakan sebagai studi kasus penelitian ini, maka dapat disimpulkan rincian mengenai unsur-unsur fasadnya:

\begin{tabular}{l}
$\begin{array}{l}\text { Tabel 2. Rumah gudang model panggung A (F4) } \\
\text { Eungsi rumahi; replika \& ruang monitor amphitheatre (6) }\end{array}$ \\
\hline Bagian fasad
\end{tabular}

Gambar 16 - 22. Rumah gudang model panggung $A$ (Sumber: Dokumentasi pribadi) 


\begin{tabular}{|c|c|c|}
\hline \multicolumn{3}{|c|}{$\begin{array}{l}\text { Tabel 3. Rumah ioglo Betawi model pangeung (F3) } \\
\text { Fungsi rumak, replika \& ryang, rias amphitheatre (6) }\end{array}$} \\
\hline Bagian fasad & Gambar & $\begin{array}{l}\text { Tergoleng } \\
\text { sebagai }\end{array}$ \\
\hline Tampak depan & & \\
\hline $\begin{array}{l}\text { Langkan sebagai } \\
\text { pagar pada teras } \\
\text { curaah berbahao } \\
\text { dastac papan \& } \\
\text { baxy. }\end{array}$ & & $\begin{array}{l}\text { Semi- } \\
\text { modern }\end{array}$ \\
\hline 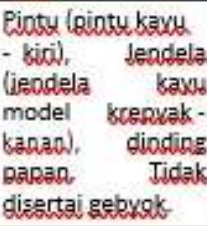 & & $\begin{array}{l}\text { Semi- } \\
\text { modern }\end{array}$ \\
\hline
\end{tabular}

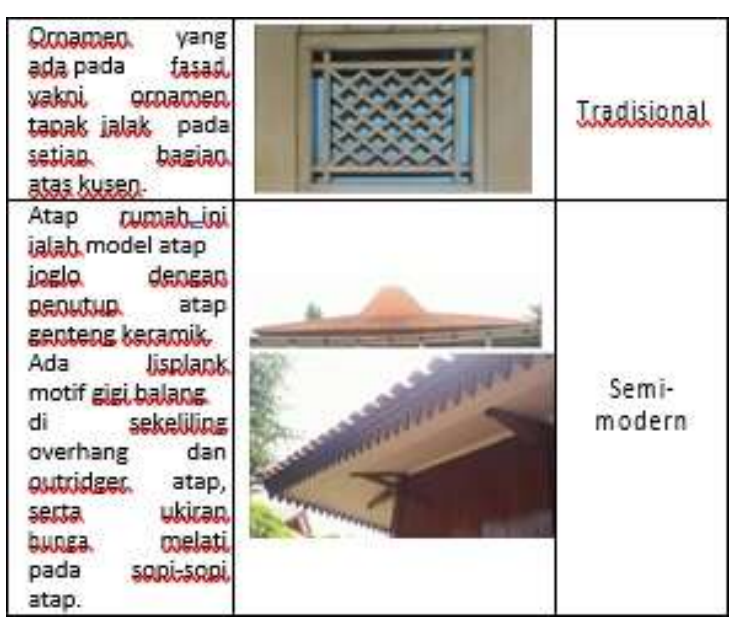

Gambar 23-28: Rumah Joglo Betawi model panggung

(Sumber: Dokumentasi pribadi)
ARSITEKTA

Tabel 4. Rumah kebaya model panggung (F2)

Fungsi rumah-irelika \& ryang rias amphitheatre (6)

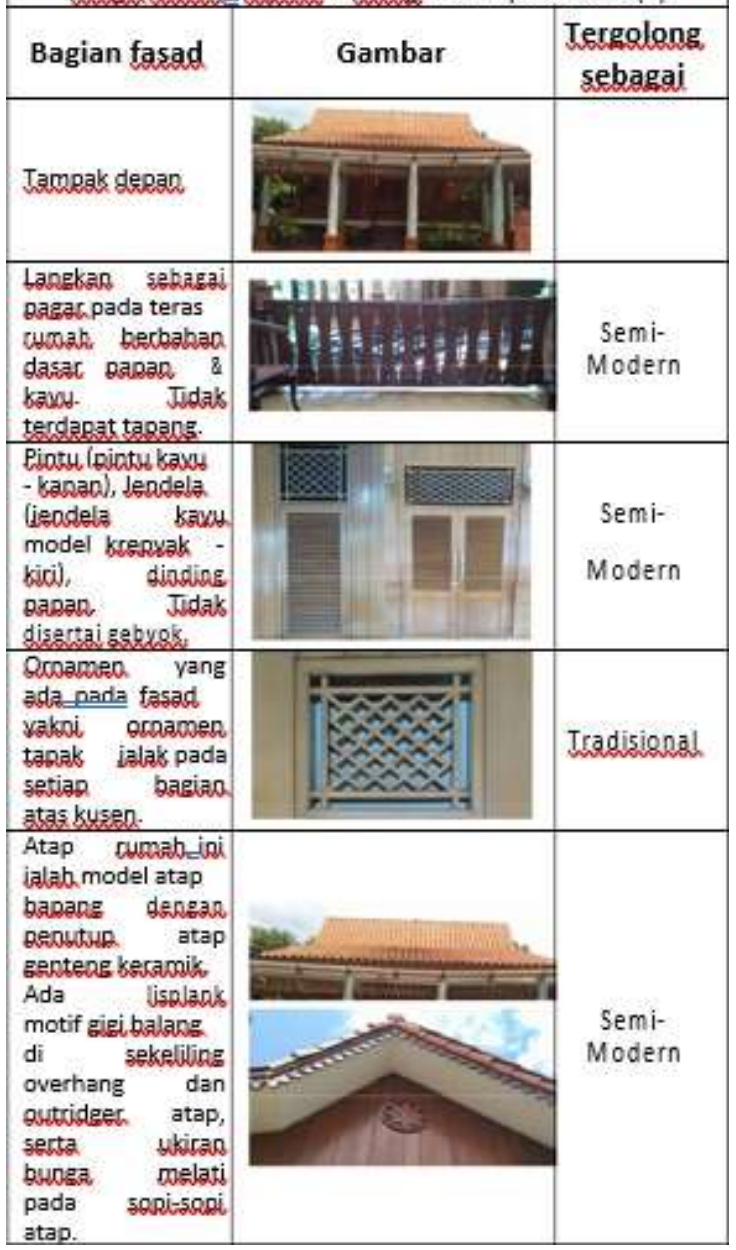

Gambar 29 - 34. Rumah kebaya model panggung (Sumber: Dokumentasi pribadi) 


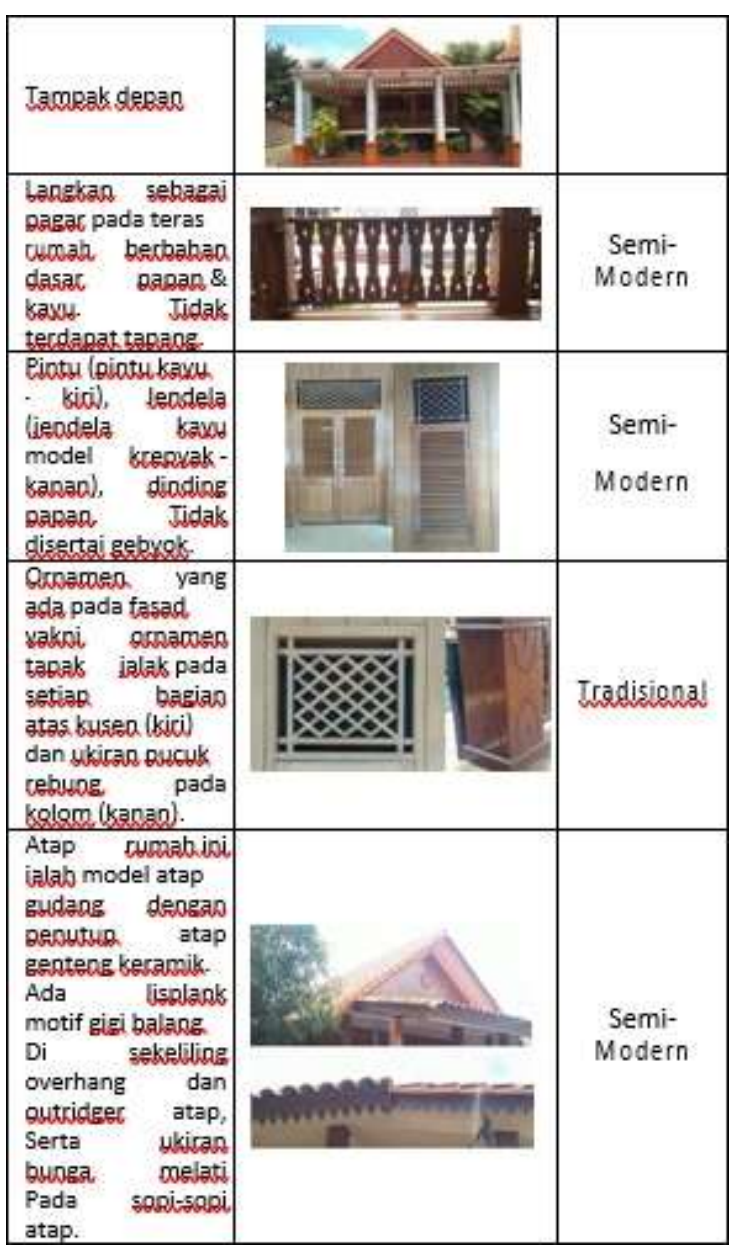

Gambar 35-40. Rumah Gudang model panggung B

(Sumber: Dokumentasi pribadi)

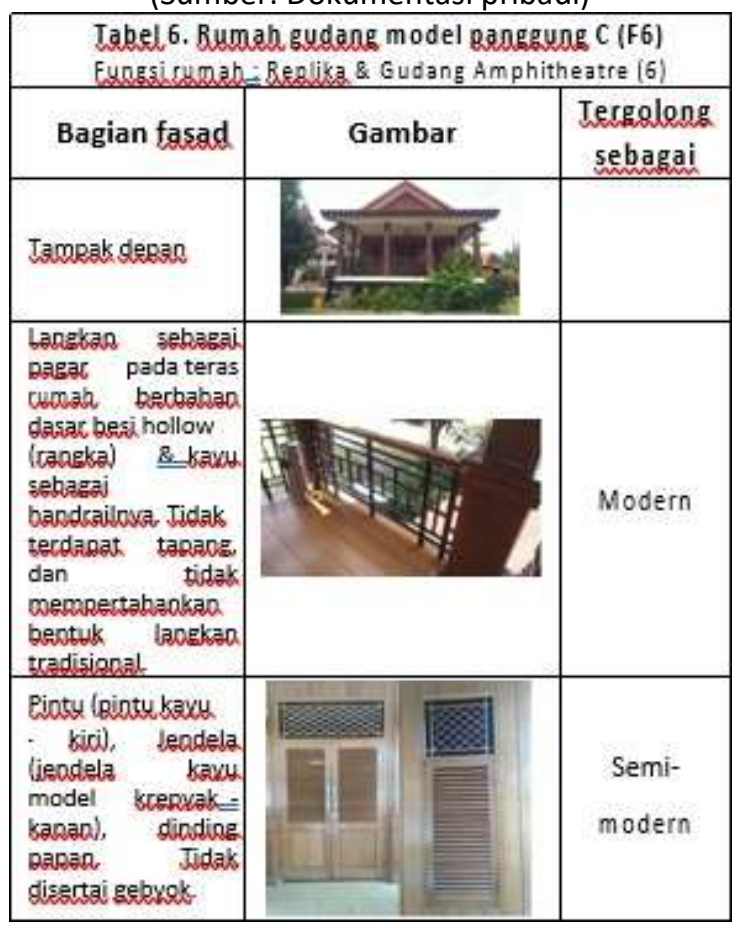

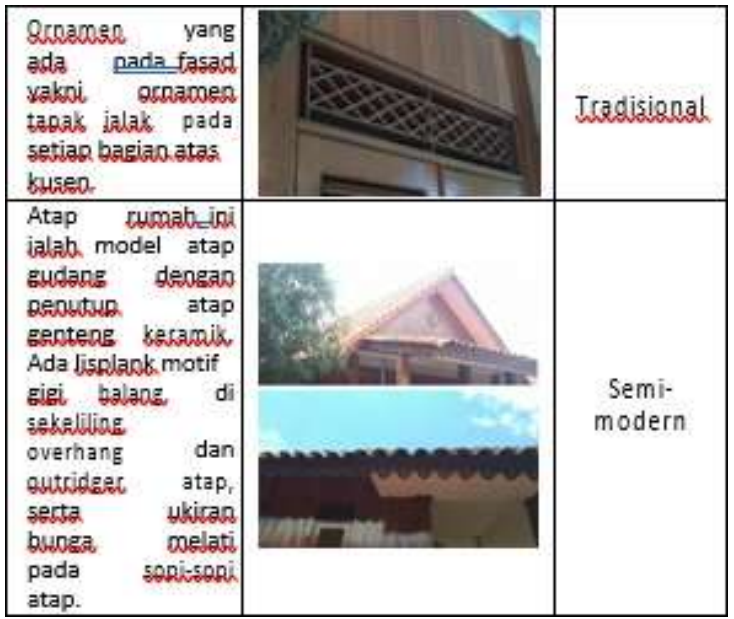

Gambar 41-46. Rumah Gudang model panggung C (Sumber: Dokumen pribadi)

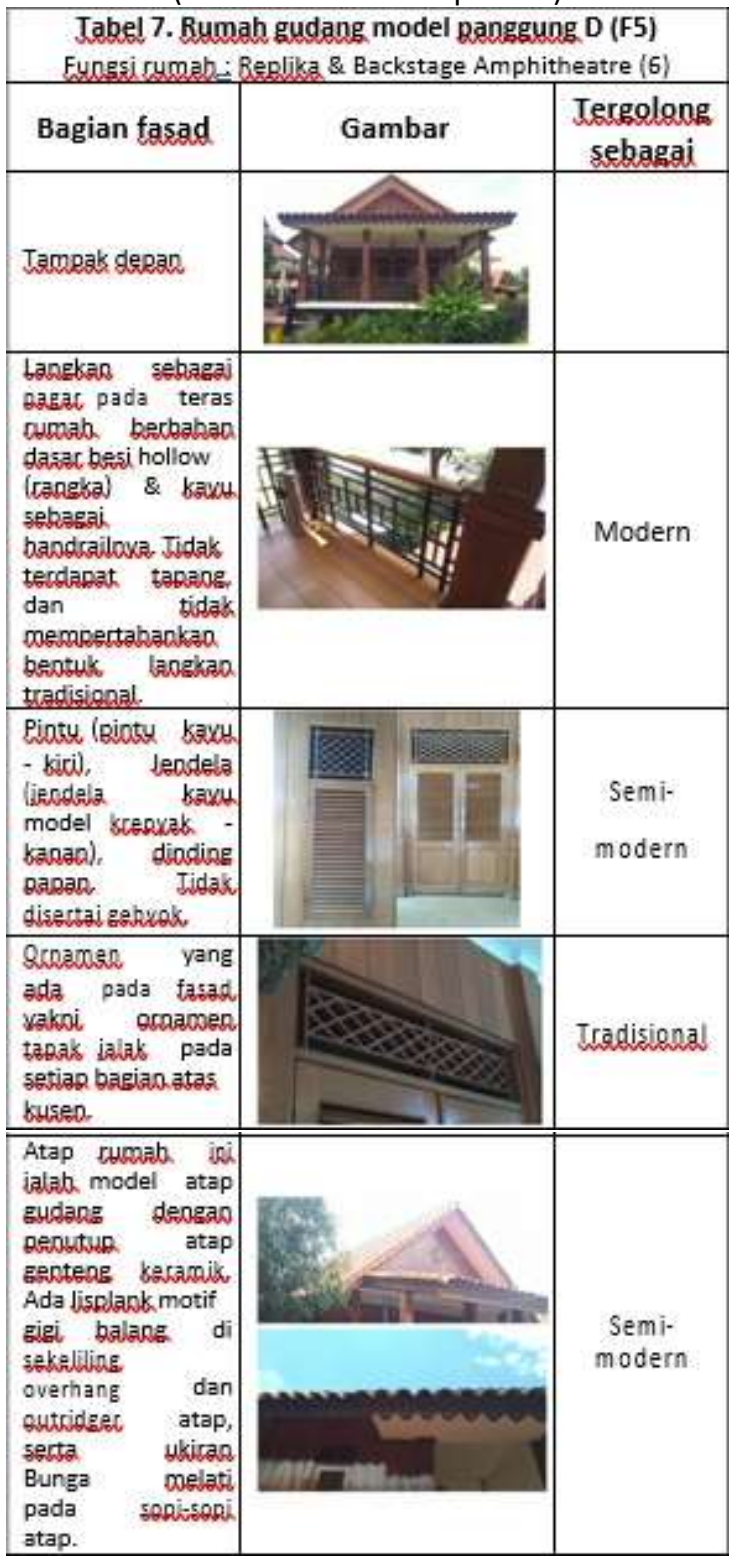

Gambar 47 - 52. Rumah gudang model panggung $D$

(Sumber: Dokumentasi pribadi) 


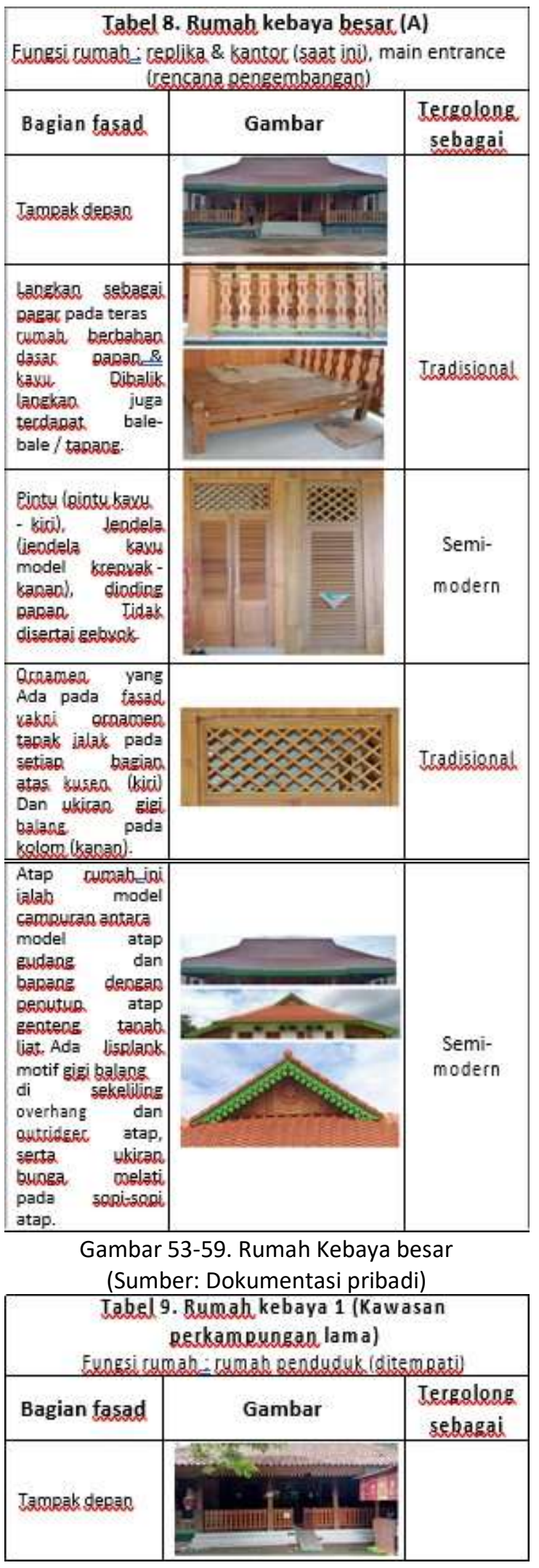

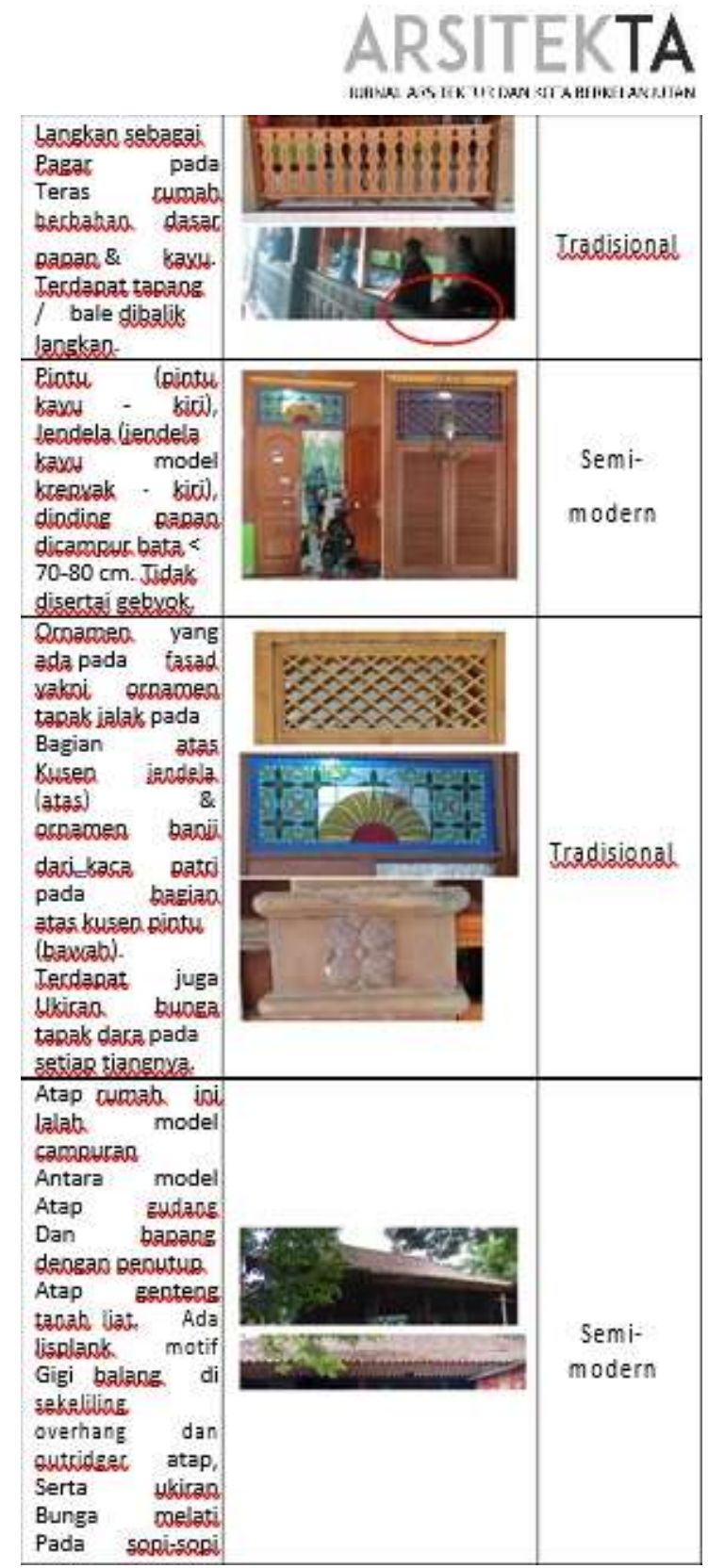

Gambar 60 - 68. Rumah kebaya 1 perkampungan lama

(Sumber: Dokumentasi pribadi) Tabel 10. Rumah kebaya 2 (Kawasan perkampungan lama) Eungsi rumah-replika \& kantor

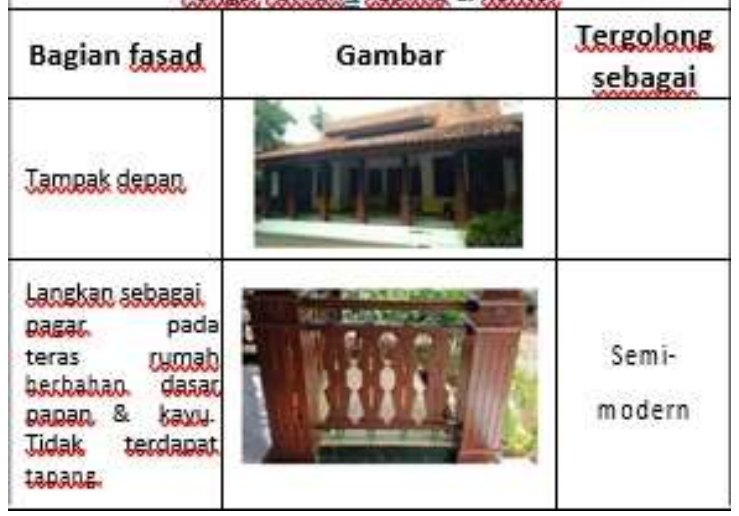




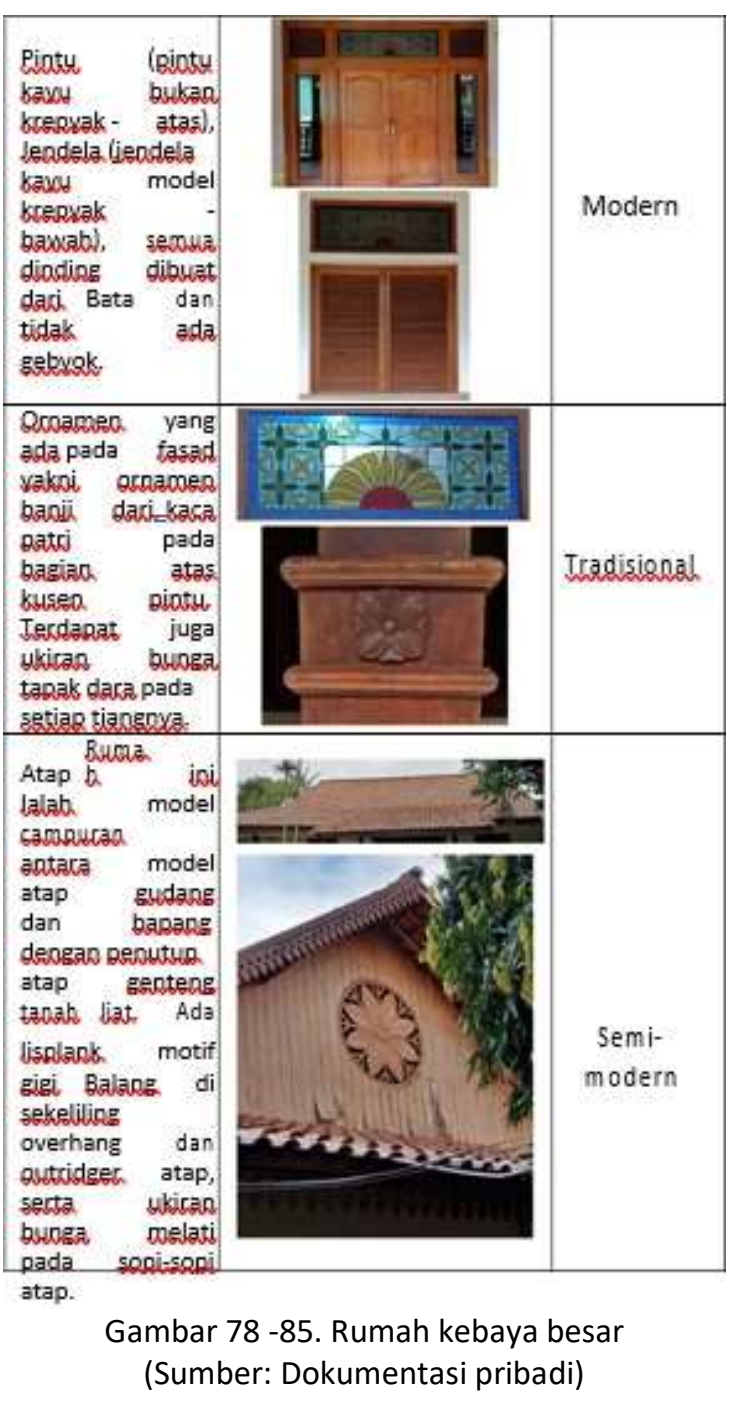

\section{KESIMPULAN}

Berdasarkan hasil analisa dokumentasi studi kasus, dapat ditarik data berikut:
ARSITEKTA

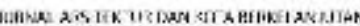

\begin{tabular}{|c|c|c|c|}
\hline \multicolumn{4}{|c|}{$\begin{array}{l}\text { Tabel 12. Hasil analisa topologi golongan unsur } \\
\text { fasade Betawi }\end{array}$} \\
\hline \multirow{2}{*}{ Studi kasus. } & \multicolumn{3}{|c|}{$\begin{array}{l}\text { Unsur dalam fasad yang } \\
\text { tergolong sebagai... }\end{array}$} \\
\hline & $\begin{array}{l}\text { Tradisi- } \\
\text { 9oal }\end{array}$ & $\begin{array}{l}\text { Semi } \\
\text { modern }\end{array}$ & Modern \\
\hline $\begin{array}{l}\text { Rumah gudang } \\
\text { model ganggung A }\end{array}$ & $1 / 4$ & $3 / 4$ & $0 / 4$ \\
\hline $\begin{array}{l}\text { Rumab joglo } \\
\text { Betawi model } \\
\text { Ranggung }\end{array}$ & $1 / 4$ & $3 / 4$ & $0 / 4$ \\
\hline $\begin{array}{l}\text { Rumah kebaya } \\
\text { model panggung }\end{array}$ & $1 / 4$ & $3 / 4$ & $0 / 4$ \\
\hline $\begin{array}{l}\text { Rumab gudang } \\
\text { model ganggung } \mathrm{B}\end{array}$ & $1 / 4$ & $3 / 4$ & $0 / 4$ \\
\hline $\begin{array}{l}\text { Rumab gudang } \\
\text { model ganggung C }\end{array}$ & $1 / 4$ & $2 / 4$ & $1 / 4$ \\
\hline $\begin{array}{l}\text { Bumah gudang } \\
\text { model gagogenos } 0\end{array}$ & $1 / 4$ & $2 / 4$ & $1 / 4$ \\
\hline $\begin{array}{l}\text { Rumah kebaya } \\
\text { kesar. }\end{array}$ & $2 / 4$ & $2 / 4$ & $0 / 4$ \\
\hline Bumah kebaya 1 & $2 / 4$ & $2 / 4$ & $0 / 4$ \\
\hline Bumah kebaya 2 & $x$ & $2 / 4$ & $1 / 4$ \\
\hline Rumah kebaya 3 & $\mathrm{x}$ & $2 / 4$ & $1 / 4$ \\
\hline TOTAL & $12 / 40$ & $24 / 40$ & $4 / 40$ \\
\hline
\end{tabular}

Dari tabel diatas, dapat disimpulkan bahwa dari 10 studi kasus fasad rumah Betawi yang berada di area Setu Babakan, keempat unsur fasad yang dinilai (atap, langkan, bukaan, dan ornamen, total 40 unsur dari 10 studi kasus), terdapat 12 unsur yang masih tergolong tradisional, 24 unsur yang sudah mulai transisi menjadi semi-modern, dan 4 unsur yang sudah tergolong modern.

\section{Hasil analisa topologi golongan unsur fasade Betawi}

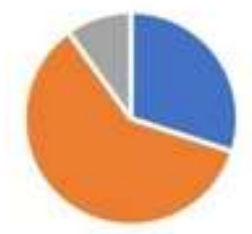

n Tradisional $=$ Semi-modern $=$ Modern

Diagram 1. Total golongan unsur fasade Rumah adat Betawi yang berada pada kawasan perkampungan budaya Betawi Setu Babakan

(Sumber: Analisa pribadi) 
Dapat disimpulkan bahwa, kebanyakan unsur fasad dari 10 rumah yang diteliti sudah didominasi oleh unsur arsitektur Betawi semimodern. Walaupun demikian, masih terdapat unsur arsitektur Betawi tradisional yang tetap dipertahankan.

\section{DAFTAR PUSTAKA}

Swadarma, Doni; Aryanto, Yunus. (2013). RUMAH ETNIK BETAWI. Griya Kreasi, Jakarta.

Belgawan Harun, Ismet. (1991). RUMAH

TRADISIONAL BETAWI. Dinas Kebudayaan, Jakarta.

Suku Betawi, [diakses pada: November $23^{\text {rd }}, 2019$ 19:45 WIB], Url:

https://www.romadecade.org/suku-betawi/

Arsitektur Tradisional Rumah Betawi, Shabrina Alfari [diakses pada: December $1^{\text {st }}, 2019$ - 12:43

WIB], Url:

https://www.arsitag.com/article/arsitekturtradisional-rumah-betawi 